\title{
DAMPAK MEDIA SOSIAL DALAM GAYA HIDUP SOSIAL ( STUDI KASUS PADA MAHASISWI PENDIDIKAN ADMINISTRASI PERKANTORAN FE UNY)
}

\author{
Rr. Chusnu Syarifa Diah Kusuma \\ Fakultas Ekonomi, Universitas Negeri Yogyakarta, Indonesia \\ chusnu@uny.ac.id
}

\begin{abstract}
Abstrak: Dampak Media Sosial dalam Gaya Hidup Sosial: (Studi Kasis pada Mahasiswi Pendidikan Administrasi Perkantoran FE UNY). Pengaruh media sosial dalam institusi pendidikan dan masayarakat sekarang ini tidak diragukan lagi. Siswa di negara maju dan berkembang menjadi lebih kecanduan media sosial dan aplikasinya karena berbagai alasan. Alasanalasan ini dapat menyebabkan perubahan dalam gaya hidup sosial dan pribadi baik secara akademis maupun di luar akademik. Penelitian ini bertujuan untuk menilai dampak dari media sosial pada gaya hidup sosial siswa khususnya mahasiswi. Penelitian ini menggunakan metodologi penelitian kuantitatif yang melibatkan instrumen penelitian kuesioner di antara 40 mahasiswi Program Studi Pendidikan Administrasi Perkantoran angkatan 2018 Fakultas Ekonomi Universitas Negeri Yogyakarta. Temuan-temuannya meliputi; media sosial memperbaiki cara berpikir mahasiswi, berinteraksi, berkomunikasi, menemukan cinta, gaya hidup sosial dan banyak lagi.
\end{abstract}

Kata kunci: media sosial, gaya hidup sosial.

\begin{abstract}
The Impact of Social Media on The Social Lifestyle (Students of the Office of Education Administration Study Program class of 2018, Faculty of Economics, Yogyakarta State University). The influence of social media in educational institutions and society today is no doubt. Students in developed and developing countries are becoming more addicted to social media and its applications for various reasons. These reasons can cause changes in social and personal lifestyles both academically and outside academia. This study aims to assess the impact of social media on the social lifestyle of students, especially college students. This research uses a quantitative research methodology involving a questionnaire research instrument among 40 students of the Office of Education Administration Study Program class of 2018, Faculty of Economics, Yogyakarta State University. The findings include; social media improves the way students think, interact, communicate, find love, social lifestyles and more.
\end{abstract}

Keyword: social media, social lifestyle

\section{PENDAHULUAN}

Selama bertahun-tahun, ada perubahan yang drastis yaitu peningkatan teknologi. Internet khususnya media sosial telah mengubah interaksi dan pola komunikasi masyarakat ketika internet dapat memberikan fasilitas "sosialisasi" melalui fasilitas media sosial maka terjadilah bentuk hubungan berdasarkan kekerabatan, untuk saling mengenal secara fisik, regional, saling membantu dalam arti bertetangga dan ramah. Media sosial membuka peluang setiap individu untuk membangun dirinya sendiri. Menciptakan dan membangun identitas individu ketika memasuki kehidupan dunia maya (media sosial). Identitas diri inilah yang akan mewakili individu untuk bersosialisasi di dunia cyber.

Kehadiran internet (media sosial) telah mengubah pola interaksi dan komunikasi individu. Beberapa peneliti CMC (computer-mediated-communication) telah meneliti bagaimana karakteristik CMC mempengaruhi pola interaksi penggunanya. Bentuk-bentuk interaksi sosial dimediasi oleh internet yang dengan mudah terhubung ke semua orang meski tidak saling kenal 
erat. Bentuk hubungan individu bukan lagi fisik tetapi "antarmuka", yaitu hubungan yang diwakili oleh perangkat (teknologi komunikasi). Dalam banyak hal, Internet harus mengendalikan dan mengatur kehidupan manusia. Dengan fasilitas internet yang disediakan pada akhirnya membuat individu selalu memiliki keinginan untuk mendokumentasikan setiap aktivitas hidupnya untuk ditampilkan di internet (media sosial). Media sosial untuk setiap individu merupakan peluang untuk membangun diri mereka sendiri. Bahkan, banyak pengguna internet yang menggunakan identitas baru. Menciptakan dan membangun identitas individu ketika memasuki kehidupan dunia maya (media sosial). Fenomena ini menarik untuk mempelajari bagaimana netizen (pengguna internet) membangun dirinya di media sosial.

Pada dasarnya, komunikasi melalui media sosial dapat membuat orang lebih mudah mengembangkan jejaring. Seperti penelitian yang dilakukan oleh Gonzales \& Hancock (2011: 82) bahwa situs jejaring sosial menyediakan sarana bagi individu untuk menampilkan diri dengan baik sebelum membangun identitas, pemikiran dan foto diri mereka untuk disebarkan kepada orang lain

Media sosial yang terutama untuk menyampaikan informasi memiliki peran penting di antara pelajar termasuk mahasiswi. Tren yang berkembang di World Wide Web (WWW) telah meningkatkan pengetahuan, berbagi dan mentransfer informasi menjadi lebih mudah dari sebelumnya. Orang-orang dari semua lapisan masyarakat sekarang dapat dengan mudah berbagi informasi, gambar dan memposting pemikiran motivasi di media sosial dan mengiklankan pekerjaan. Dengan kemajuan teknologi, semua ini dapat dilakukan, bahkan di tempat tidur atau kamar tidur, seseorang pada waktu nyamannya menggunakan smartphone, tablet, atau komputer pribadi. Dengan munculnya media sosial ini secara global, banyak mahasiswi memanfaatkan media secara bijak untuk memperoleh lebih banyak pengetahuan, sementara itu, banyak dari mereka mencurahkan sebagian besar waktunya untuk hal-hal yang tidak menambah nilai bagi akademik mereka seperti terus-menerus mengobrol dan mengunggah gambar yang berbeda. Media sosial hanya merujuk pada alat online yang dibuat untuk tujuan interaksi dan berbagi konten di antara orang-orang di komunitas (Nyangeni, Du Rand \& Van Rooyen, 2015). Dalam konteksnya yang lebih luas, media sosial meliputi; teknologi berbasis web seperti YouTube (layanan berbagi video sosial), tes pesan, blog, mikroblog seperti Twitter, layanan jejaring sosial (misal Facebook, MySpace, WhatsApp).

Banyak penelitian telah dilakukan pada penggunaan media sosial pelajar, dampaknya pada perilaku sosial, pendidikan, kinerja akademik serta dampak positif dan negatifnya, faktor-faktor yang mempengaruhi penggunaan, penggunaan etis dan lainnya (Al-Sharq, Hashim \& Kutbi, 2015; Wolf, Wenskovitch \& Anton, 2016; Mingle \& Adams, 2015). Penggunaan media sosial oleh kaum 
muda telah menjadi cara hidup dan aktivitas pribadi yang dibuat untuk publik (Edge, 2017). Khan (2012) melakukan penelitian yang berfokus pada dampak situs web media sosial pada siswa. Sedangkan studi Ahn (2011) membahas efek media sosial terhadap kemajuan akademik dan kesejahteraan sosial remaja. Meskipun informasi terbatas diketahui tentang dampak media sosial atau media baru pada gaya hidup sosial mahasiswi. Menurut Rajeev (2015), media sosial mempengaruhi berbagai masyarakat dalam memungkinkan individu untuk membuat pandangan dan kehidupan mereka menjadi publik. Sementara Shabir, Hameed, Safdar dan Gilani (2014) mengemukakan bahwa gaya hidup sosial remaja dipengaruhi oleh media sosial, terkadang dampaknya bisa negatif.

Media sosial menjadi bagian dari masyarakat, mengubah norma dan budaya sosial (AlSharq, Hashim \& Kutbi, 2015). Berbagi informasi dan konten sekarang menjadi keinginan sosial (Wolf et al., 2015). Hal Ini telah mengubah berapa banyak orang, termasuk pelajar terutama mahasiswi dalam berinteraksi, berkomunikasi dan bersosialisasi di lembaga pendidikan. Media baru seperti yang disebut sebagian besar menyediakan konektivitas yang kuat, komunikasi dan berbagi konten di antara siswa dan seluruh masyarakat. Siswa sekarang dapat berpartisipasi dalam diskusi sosial, memposting komentar, gambar, video, berbagi ide dan banyak lagi. Pada titik ini, dapat dikatakan bahwa media sosial mempengaruhi jalur kehidupan sehari-hari remaja dan khususnya para siswa (Rajeev, 2015)

Media sosial menciptakan saluran untuk konektivitas, komunikasi, diskusi, dan interaksi di antara orang-orang. Saluran ini menyediakan berita dan informasi lintas gender. Shabir et al. (2014), percaya bahwa media sosial mempengaruhi remaja termasuk wanita. Peristiwa dunia saat ini dipengaruhi oleh media sosial karena penelitian membuktikan bahwa 50\% orang setiap hari mendapat berita instan melalui saluran media sosial (Lowisz, 2014). Tidak diragukan lagi, penggunaan media sosial telah mempengaruhi perasaan sosial dan manusia. Perasaan ini dapat mengakibatkan rasa sakit, terluka, gangguan mental dan emosional (Williams, 2012), krisis dalam pernikahan dan banyak lagi. Tetapi studi tentang efek media sosial pada diskontinuitas pernikahan sedikit. Lebih lanjut, Williams (2012) berpendapat bahwa penggunaan Facebook yang tidak efektif oleh pasangan dapat menyebabkan keruntuhan hubungan. Studi ini juga menyinggung bahwa penggunaan Facebook mempengaruhi hubungan dan terus mengubah lanskap interaksi manusia. Peneliti lebih lanjut menyatakan bahwa media sosial mempengaruhi budaya dan sistem kepercayaan pengguna, nilai, agama, "budaya pop", politik dan banyak lagi. Media sosial dapat dikatakan digunakan secara luas oleh mahasiswi daripada rekan pria karena berbagai alasan dan kegiatan. 
Gross (2004) menyatakan bahwa penggunaan media sosial telah melonjak begitu tinggi selama beberapa dekade terakhir yang telah meningkatkan banyak harapan seperti; a) prediksi penggunaan media sosial berdasarkan gender ketika anak laki-laki tampaknya menghabiskan sebagian besar waktu mereka menjelajahi internet sementara anak perempuan terlibat dalam obrolan, b) bahwa penggunaan media sosial mengarah pada depresi dan isolasi remaja, c) bahwa remaja menggunakan media sosial untuk beragam hal yang tidak diketahui. Media sosial jika digunakan secara bijak dapat berfungsi sebagai jalan yang baik untuk pembelajaran kolaboratif bagi siswa (Chen, Kaewkitipong \& Ractham, 2016). Jha, Shah, Basnet, Paudel, Sah, Sah dan Adhikari (2016) menyatakan bahwa Facebook adalah salah satu jenis aplikasi media sosial yang banyak digunakan di segala usia dan profesi. Aplikasi media sosial dapat dinilai dari perangkat seperti komputer dan di mana saja kapan saja dengan tujuan menghubungkan teman dan simpatisan, berinteraksi dan berbagi ide pribadi. Selain itu, penggunaan media sosial seperti Facebook dapat menyebabkan perilaku adiktif dan ketergantungan di kalangan siswa yang membutuhkan perhatian. Juga penggunaan media sosial oleh siswa dapat menyebabkan masalah harga diri, depresi dan sulit tidur.

Dengan peningkatan teknologi, penelitian telah membuktikan bahwa media sosial memainkan peran besar dalam pertumbuhan ekonomi, menyatukan teman-teman dan memungkinkan menjalin pertemanan baru. Sementara itu konsekuensi meliputi; serangan teroris, cyber bullying, perburuan untuk eksploitasi seksual dan pemborosan waktu (Makinde, Odimegwu, Abdulmlik, Babalola \& Fawole, 2016). Penelitian lain juga melaporkan bahwa penggunaan media sosial telah menyebabkan serangkaian kekerasan perempuan melalui pertemuan yang diatur dengan teman-teman laki-laki media sosial. Pekerjaan Junco, Helbergert dan Loken (2011) sejalan dengan karya terbaru yang mempertahankan bahwa media sosial mencakup situs web Internet, layanan dan praktik yang meningkatkan pertukaran informasi di antara orang-orang. Salah satu situs internet seperti Facebook yang juga merupakan media sosial yang paling banyak digunakan di kalangan siswa dengan efek pada kinerja pendidikan mereka.

\section{Dampak media sosial pada gaya hidup sosial}

Tata dunia baru telah ada. Era informasi yang dibawa oleh perubahan internet telah membentuk dunia media sosial. Media sosial telah menciptakan dunia baru informasi, komunikasi, dan urutan interkonektivitas yang tidak dapat diaktifkan menggunakan metode tatap muka di antara para siswa (Al-Sharq et al., 2015; Chukwuere \& Onyebukwa, 2017). Dengan media sosial, masalah-masalah mendesak dalam masyarakat dibahas dan diberi perhatian (Shabir et al. 2014). Namun, beberapa tahun yang lalu, siswa institusi pendidikan tinggi terlibat dalam penggunaan 
berlebihan media sosial yang telah menimbulkan perdebatan tentang apakah penggunaan media sosial telah berdampak pada gaya hidup sosial, kesejahteraan dan perilaku mereka (Al-Sharq et al., 2015). Menurut Al-Sharq et al. (2015), tingkat perubahan yang dibawa oleh media sosial telah memotivasi tutor, siswa, lembaga pendidikan dan pemangku kepentingan lainnya untuk meningkatkan interaksi mereka dan teknik penyampaian pengajaran dan pembelajaran. Adopsi media sosial ke dalam pendidikan dan dalam kehidupan pada umumnya dikaitkan dengan fitur yang berorientasi pengguna, murah dan mudah digunakan dan lain-lain (Chukwuere \& Onyebukwa, 2017).

Siswa menggunakan media sosial lintas departemen yang berbeda termasuk keperawatan, sistem informasi dan banyak lainnya. Juga karena berbagai alasan seperti berkomunikasi dengan teman-teman, akses ke konten pembelajaran dan berbagi, forum diskusi kelompok, ruang obrolan, kesenangan dan banyak lagi (Al-Sharq et al., 2015). Pada titik ini, penggunaan media sosial di kalangan mahasiswa dapat membawa dampak positif dan negatif. Al-Sharq et al (2015) lebih lanjut menyatakan bahwa media sosial menciptakan pola pikir inovatif baru pada siswa serta meningkatkan interaksi dan hubungan antar-sosial antara siswa dan pendidik. Media baru ini bisa menimbulkan kecanduan, menyita waktu, mengganggu, isolasi sosial, monophobia dan lainnya.

Mingle dan Adams (2015) lebih lanjut menegaskan bahwa media sosial mengubah pengaturan pendidikan dan perilaku peserta didik. Platform memaparkan siswa untuk memposting konten dan tampilan yang tidak etis (Edge, 2017). Tingkat perubahan dari media sosial adalah salah satu inovasi dari abad ke 21. Tetapi media sosial dapat menyebabkan kerugian bagi pengguna (Moate, Chukwuere \& Mavhungu, 2017). Mingle dan Adams (2015) juga mengemukakan bahwa penggunaan media sosial secara negatif menyebabkan tulisan tangan dan ejaan yang buruk, keterlambatan untuk pengajuan kelas dan tugas, kecanduan, sedikit waktu belajar dan lain-lain. Efek negatif ini dapat divisualisasikan pada perubahan gaya hidup sosial atau sistem kepercayaan budaya.

\section{METODE}

Studi ini menggunakan sumber data primer dan data sekunder. Sumber data primer dikumpulkan melalui kuesioner sementara data sekunder juga dibangun menggunakan studi literatur. Penelitian ini berfokus pada dampak media sosial pada gaya hidup sosial mahasiswi. Penelitian ini menggunakan metode pengambilan purposive sample di Universitas Negeri Yogyakarta. Ukuran sampel 40 mahasiswi program studi pendidikan administrasi perkantoran angkatan 2018 dilibatkan dalam penelitian ini melalui teknik pengumpulan data kuesioner. 
Kemudian, metode penelitian deskriptif digunakan dalam memahami dan mengeksplorasi efek media sosial pada gaya hidup sosial mahasiswi.

Pertanyaan penelitian

1. Apa dampak dari media sosial pada gaya hidup sosial mahasiswi?

2. Apa sikap dan persepsi mahasiswi terhadap dampak media sosial terhadap gaya hidup sosial mereka?

3. Sampai sejauh mana media sosial mengubah gaya hidup sosial mahasiswi? (Positif dan negatif).

\section{HASIL DAN PEMBAHASAN}

\section{Apa dampak dari media sosial pada gaya hidup sosial mahasiswi?}

Penggunaan media sosial memiliki dampak besar pada gaya hidup sosial pengguna. Menurut Chen et al (2016), penggunaan media sosial meningkatkan pembelajaran kolaboratif di kalangan siswa. Juga, ada diskusi yang sedang berlangsung tentang apakah penggunaan media sosial mempengaruhi perilaku sosial, gaya hidup dan kesejahteraan siswa (Al-Sharq et al., 2015). Untuk mengatasi diskusi dengan jelas, pertanyaan penelitian ini bertujuan untuk menentukan dampak media sosial pada gaya hidup sosial mahasiswi.

Tabel 1. Aplikasi Media Sosial Pilihan oleh Mahasiswi

\begin{tabular}{|l|l|r|r|}
\hline \multicolumn{2}{|c|}{ Pertanyaan } & \multicolumn{2}{c|}{ Respon } \\
\cline { 3 - 4 } Manakah berikut ini aplikasi media sosial yang Anda sukai ? & \multicolumn{1}{|c|}{$\boldsymbol{N}$} & Persentase \\
\cline { 2 - 4 } & WhatsApp & 35 & $87.5 \%$ \\
\cline { 2 - 4 } & Facebook & 2 & $5 \%$ \\
\cline { 2 - 4 } & Instagram & 34 & $85 \%$ \\
\cline { 2 - 4 } & YouTube & 31 & $77.5 \%$ \\
\cline { 2 - 4 } & Twitter & 13 & $32.5 \%$ \\
\cline { 3 - 5 } & Skype & 0 & 0 \\
\hline
\end{tabular}

Sesuai dengan Tabel 1, temuan menunjukkan bahwa 35 (87,5\%) mahasiswi lebih suka menggunakan whatsApp, 34 (85\%) menggunakan instagram, sementara 31 (77.5\%) lebih suka youtube dan 13 (32.5\%) mahasiswi menyukai twitter. Namun, menurut penelitian oleh Jha et al. (2016), Facebook adalah aplikasi media sosial yang paling banyak digunakan dan digunakan di berbagai profesi untuk menghubungkan teman dan kolega. Tetapi penelitian ini menyarankan WhatsApp untuk menjadi aplikasi media sosial pilihan. 
Tabel 2. Dampak Media Sosial Pada Gaya Hidup Sosial Mahasiswi

\begin{tabular}{|c|c|c|c|c|c|c|c|}
\hline Pertanyaan & $S S$ & $S$ & Total & $T S$ & STS & Total & Bimbang \\
\hline \multirow{2}{*}{$\begin{array}{l}\text { Apakah penggunaan media sosial } \\
\text { berdampak pada gaya hidup sosial } \\
\text { mahasiswi? }\end{array}$} & 14 & 24 & 38 & 1 & 0 & 1 & 1 \\
\hline & $35 \%$ & $60 \%$ & $95 \%$ & $2.5 \%$ & 0 & $2.5 \%$ & $2.5 \%$ \\
\hline \multirow{2}{*}{$\begin{array}{l}\text { Apakah penggunaan media sosial } \\
\text { mempromosikan norma dan nilai } \\
\text { sosial yang baik? }\end{array}$} & 3 & 19 & 22 & 12 & 0 & 12 & 6 \\
\hline & $7,5 \%$ & $48 \%$ & $55 \%$ & $30 \%$ & 0 & $30 \%$ & $15 \%$ \\
\hline \multirow{2}{*}{$\begin{array}{l}\text { Apakah memposting konten-konten } \\
\text { dan tautan yang tidak relevan, rasis, } \\
\text { kekerasan, anti-budaya dan agama } \\
\text { mempromosikan kebencian di } \\
\text { antara kelompok ras di masyarakat? }\end{array}$} & 5 & 19 & 24 & 9 & 3 & 12 & 4 \\
\hline & $13 \%$ & $48 \%$ & $60 \%$ & $22.5 \%$ & $7.5 \%$ & $30 \%$ & $10 \%$ \\
\hline \multirow{2}{*}{$\begin{array}{l}\text { Apakah penggunaan media sosial } \\
\text { oleh mahasiswi tidak menghargai } \\
\text { institusi pernikahan di masyarakat? }\end{array}$} & 0 & 0 & 0 & 21 & 8 & 29 & 11 \\
\hline & 0 & 0 & 0 & $53 \%$ & $20 \%$ & $72.5 \%$ & $27.5 \%$ \\
\hline
\end{tabular}

Tabel 2, 3 dan 5 hasil disajikan sebagai berikut: Sangat setuju (SS) + Setuju (S) = Setuju (S), Tidak setuju (TD) + Sangat tidak setuju (STS) = Tidak setuju (TD) dan bimbang atau ragu-ragu berdiri sendiri. Studi ini berfokus pada setuju dan tidak setuju. Namun, hasil mahasiswi yang belum memutuskan tidak dipertimbangkan dalam analisis karena pendapat mereka tidak dapat dicocokkan dengan kategori apa pun (setuju atau tidak setuju).

Literatur dan diskusi tentang dampak media sosial pada gaya hidup sosial siswa telah dibahas dan diteliti oleh para peneliti. Literatur dari penelitian ini menyoroti dampak media sosial dalam berbagai cara. Studi ini menemukan bahwa $38(95 \%)$ dari mahasiswi menyatakan bahwa media sosial telah berdampak pada gaya hidup sosial mereka. Studi ini sesuai dengan para peneliti (AlSharq, Hashim \& Kutbi, 2015; Wolf, Wenskovitch \& Anton, 2016; Mingle \& Adams, 2015) mereka percaya bahwa media sosial berdampak pada siswa baik pada perilaku sosial, pendidikan dan lainnya. Temuan menunjukkan bahwa media sosial berdampak pada gaya hidup sosial mahasiswi.

Sebuah kuesioner digunakan untuk menentukan apakah media sosial mempromosikan norma dan nilai sosial yang baik dalam tabel 2. Studi ini menemukan bahwa 22 (55\%) mahasiswi sangat percaya bahwa media sosial mempromosikan norma dan nilai sosial yang baik dan lebih baik. Norma dan nilai-nilai inilah yang membentuk kembali makhluk sosial yang mempromosikan masyarakat yang sehat dan lebih baik secara luas. Al-Sharq et al. (2015) temuan penelitian mendukung penelitian ini menunjukkan bahwa media sosial telah membawa norma sosial dan perubahan budaya. Temuan lebih lanjut menunjukkan bahwa 12 (30\%) dari peserta tidak setuju pada media sosial mempromosikan norma dan nilai sosial yang baik. 
Menurut pertanyaan berikutnya yang menyatakan, "apakah penempatan konten dan tautan yang tidak relevan, rasis, kasar, anti-budaya dan agama mempromosikan kebencian di antara kelompok ras di masyarakat?". Pertanyaan tersebut bertujuan untuk menentukan apakah posting media sosial yang kasar atau tidak etis / anti-budaya mempromosikan kebencian di masyarakat. Temuan ini menemukan bahwa $58(84,0 \%)$ dari mahasiswi menerima bahwa beberapa posting media sosial mempromosikan kebencian dalam antar-ras, masyarakat dan mungkin dunia pada umumnya. Pernikahan yang sehat dapat menghasilkan masyarakat yang terstruktur dan sehat. Sebuah pertanyaan diminta untuk mengidentifikasi apakah media sosial memiliki pengaruh pada pandangan struktural atau konvensional mahasiswi sehubungan dengan pernikahan. Sebuah studi oleh (Williams, 2012) membuktikan bahwa Facebook sebagai aplikasi media sosial mempengaruhi hubungan termasuk pernikahan. Temuan ini menyatakan bahwa 29 (72.5\%) dari responden tidak setuju bahwa penggunaan media sosial tidak merendahkan persepsi dan konsep pernikahan di masyarakat. Temuan ini membuktikan bahwa tidak peduli dampak media sosial di masyarakat, pernikahan tetap bertahan.

Bagaimana sikap dan persepsi siswa perempuan terhadap dampak media sosial terhadap gaya hidup sosial mereka?

Sikap terhadap teknologi dapat dipengaruhi oleh persepsi pengguna yang dapat mengarah pada penerimaan. Hal ini berarti bahwa persepsi mengarah pada sikap (positif atau negatif) yang menghasilkan penerimaan atau tidak. Pertanyaan ini berfungsi untuk memahami sikap mahasiswi dan dampak persepsi media sosial terhadap gaya hidup sosial.

Tabel 3: Sikap dan Persepsi Mahasiswi Pada Media Sosial Berdampak Pada Gaya Hidup Sosial

\begin{tabular}{|c|c|c|c|c|c|c|c|}
\hline Pertanyaan & $S S$ & $S$ & Total & $T S$ & STS & Total & Bimbang \\
\hline \multirow{2}{*}{$\begin{array}{l}\text { Media sosial baik untuk pembelajaran } \\
\text { pendidikan }\end{array}$} & 6 & 29 & 35 & 3 & 0 & 3 & 2 \\
\hline & $15 \%$ & $73 \%$ & $87 \%$ & $8 \%$ & 0 & $8 \%$ & $5 \%$ \\
\hline \multirow{2}{*}{$\begin{array}{l}\text { Penggunaan media sosial memberi } \\
\text { pengaruh negative interaksi pribadi } \\
\text { (gaya hidup sosial)? }\end{array}$} & 2 & 18 & 20 & 16 & 2 & 18 & 2 \\
\hline & $5 \%$ & $45 \%$ & $50 \%$ & $40 \%$ & $5 \%$ & $45 \%$ & $5 \%$ \\
\hline \multirow{2}{*}{$\begin{array}{l}\text { Penggunaan media sosial } \\
\text { mempromosikan posting video, } \\
\text { gambar, gambar yang tidak bermoral } \\
\text { dan tidak etis di kalangan mahasiswi? }\end{array}$} & 1 & 6 & 7 & 23 & 5 & 28 & 5 \\
\hline & $2.5 \%$ & $15 \%$ & $17.5 \%$ & $57.5 \%$ & $12.5 \%$ & $70 \%$ & $12.5 \%$ \\
\hline \multirow{2}{*}{$\begin{array}{l}\text { Penggunaan media sosial menciptakan } \\
\text { informasi yang tidak perlu dan } \\
\text { kebingungan dalam pikiran } \\
\text { mahasiswi? }\end{array}$} & 1 & 10 & 11 & 22 & 3 & 25 & 4 \\
\hline & $2.5 \%$ & $25 \%$ & $27.5 \%$ & $55 \%$ & $7.5 \%$ & $62.5 \%$ & $10 \%$ \\
\hline \multirow{2}{*}{$\begin{array}{l}\text { Penggunaan media sosial berdampak } \\
\text { positif pada mahasiswi? }\end{array}$} & 2 & 27 & 29 & 1 & 0 & 1 & 10 \\
\hline & $5 \%$ & $68 \%$ & $72.5 \%$ & $2.5 \%$ & 0 & $2.5 \%$ & $25 \%$ \\
\hline
\end{tabular}


Pertanyaan pertama pada tabel 3 mengatakan "media sosial baik untuk pembelajaran pendidikan saat ini?". Temuan melaporkan bahwa 35 (87\%) dari peserta setuju kuat bahwa media sosial mempromosikan pengajaran dan pembelajaran pendidikan abad ke-21 yang baik. Temuan ini didukung oleh Chen et al. (2016), mereka sepakat bahwa media sosial dapat berkontribusi dengan sangat baik dalam pendidikan dalam cara mempromosikan pembelajaran kolaboratif di kalangan siswa, jika diterapkan dengan benar. Temuan ini merupakan indikasi bahwa media sosial adalah pengembangan dan inisiatif yang disambut baik di lingkungan pendidikan abad ke-21.

Pertanyaan kedua dimaksudkan untuk menemukan apakah media sosial berpengaruh negatif terhadap interaksi pribadi (gaya hidup sosial) mahasiswi. Menurut Shabir et al. (2014), mereka menegaskan bahwa kadang-kadang, remaja dipengaruhi secara negatif oleh media sosial. Sesuai dengan penelitian ini pada tabel 3, 20 (50\%) dari peserta menyinggung kuat bahwa media sosial secara negatif mempengaruhi gaya hidup sosial dan interaksi mereka di masyarakat. Temuan membuktikan bahwa mayoritas tanggapan setuju bahwa media sosial memiliki dampak negatif pada interaksi gaya hidup sosial. Dampaknya mungkin dihasilkan dari persepsi mereka yang mengontrol sikap (positif atau negatif).

Penelitian lebih lanjut disajikan dengan 7 (17.5\%) dari mahasiswi setuju bahwa media sosial mempromosikan posting video, gambar, gambar yang tidak bermoral dan tidak etis di antara mahasiswi. Sementara 28 (70\%) tidak percaya bahwa media sosial mendorong posting video, gambar, komentar, dan banyak lagi yang tidak etis oleh mahasiswi. Temuan menunjukkan bahwa secara keseluruhan, penggunaan media sosial tidak selalu secara tidak bijaksana mempromosikan posting yang tidak etis dari konten pribadi-pribadi online yang paling sering menjadi bumerang pada pencipta konten atau pemilik akun. Hasil temuan tidak menunjukkan bahwa media sosial mempromosikan posting konten yang tidak etis secara online.

Penggunaan besar-besaran media sosial telah merekayasa informasi positif dan negatif dan menciptakan kebingungan juga. Untuk memastikan apakah penggunaan media sosial telah menciptakan gambar yang tidak perlu, informasi (konten) berbagi dan kebingungan (positif dan negatif) di benak mahasiswi, maka, pertanyaan keempat (4) diajukan. Penelitian ini menemukan bahwa $11(27.5 \%)$ dari mahasiswi sangat setuju bahwa media sosial telah menciptakan yang tidak perlu dan kebingungan di benak mahasiswi. Temuan menunjukkan bahwa mahasiswi tidak percaya bahwa media sosial menciptakan informasi atau konten yang berlebihan di kalangan mahasiswi yang menyebabkan kebingungan tentang apa yang harus dipercaya dan apa yang tidak boleh percaya. 
Pertanyaan kelima (5) pada tabel 3 mencari pemahaman peserta untuk memastikan apakah media sosial berdampak positif pada mahasiswi. Ada sejumlah penelitian yang menunjukkan fakta bahwa penggunaan media sosial berdampak pada siswa termasuk mahasiswi. Kemudian, 29 (72.5\%) dari peserta sangat setuju bahwa media sosial memiliki dampak positif pada mahasiswi. Sementara $1(2.5 \%)$ percaya bahwa media sosial tidak berdampak positif bagi mereka. Temuan keseluruhan menunjukkan bahwa media sosial berdampak positif dan mempengaruhi mahasiswi.

Tabel 4: Konstruksi Gaya Hidup Sosial yang Paling Mempengaruhi Media Sosial

\begin{tabular}{|l|l|r|r|}
\hline \multicolumn{2}{|c|}{ Pertanyaan } & \multicolumn{2}{c|}{ Respon } \\
\cline { 3 - 4 } & \multicolumn{1}{|l|}{$\boldsymbol{N}$} & \multicolumn{1}{c|}{ Persentase } \\
\hline $\begin{array}{l}\text { Di mana dari berikut ini } \\
\text { konstruksi gaya hidup sosial }\end{array}$ & Ketertarikan/ hobi/minat & 23 & $57.5 \%$ \\
\cline { 2 - 4 } $\begin{array}{l}\text { yang paling mempengaruhi } \\
\text { media sosial? }\end{array}$ & Budaya & 22 & $55 \%$ \\
\cline { 2 - 4 } & Kepercayaan & 8 & $20 \%$ \\
\cline { 2 - 4 } & Pendapat dalam hidup & 23 & $57.5 \%$ \\
\cline { 2 - 4 } & Tingkah laku & 19 & $47.5 \%$ \\
\cline { 2 - 4 } & Orientasi perilaku (kelompok dan individu) & 21 & $52.5 \%$ \\
\cline { 2 - 4 } & Pemikiran & 27 & $67.5 \%$ \\
\cline { 2 - 4 } & Posisi sosial & 18 & $45 \%$ \\
\cline { 2 - 4 } & Tindakan & 3 & $40 \%$ \\
\cline { 2 - 4 } & Asosiasi & 5 & $7.5 \%$ \\
\cline { 2 - 4 } & Norma & & $12.5 \%$ \\
\hline
\end{tabular}

Ada berbagai konstruksi gaya hidup sosial yang dapat berdampak pada media sosial. Tabel 4 menyajikan konstruksi tersebut. Menurut Al-Sharq et al. (2015), ada perdebatan yang sedang berlangsung tentang apakah media sosial berdampak pada gaya hidup sosial, kesejahteraan dan perilaku pengguna. Sedangkan Mingle dan Adams (2015) menyatakan bahwa media sosial mengubah perilaku siswa. Tabel 4 menyajikan temuan yang menunjukkan 27 (67.56\%) dari peserta menunjukkan bahwa media sosial berdampak pada pemikiran mereka, pendapat dalam hidup dan ketertarikan/hobi masing-masing 23 (57.5\%), budaya 22 (55\%), orientasi perilaku (kelompok dan individu 21(52.5\%). Posisi sosial 18 (45s\%), dan banyak lagi. Temuan menunjukkan bahwa kehadiran media sosial berdampak pada perilaku mahasiswi yang dapat menyebabkan perubahan dalam perilaku sosial, pendapat hidup (opini dalam kehidupan), posisi sosial, ketertarikan/minat/hobi, pemikiran, kepercayaan, budaya, orientasi perilaku (kelompok dan individu), tindakan, asosiasi dan norma. Semua konstruksi ini adalah komponen gaya hidup sosial dari seorang individu. Kemudian temuan menunjukkan bahwa media sosial memiliki dampak langsung pada semuanya. 


\section{Sampai sejauh mana media sosial mengubah gaya hidup sosial mahasiswi?}

Media sosial membawa perubahan gaya hidup sosial. tingkat perubahan yang dibawa oleh media sosial telah memotivasi siswa, pemuda, pengajar, dan lembaga akademis (Al-sharq et al, 2015) dan mereka suka mengadopsinya ke dalam kegiatan dan operasi kehidupan sehari-hari mereka. Menurut Mingle dan Adams (2015), media sosial membawa perubahan perilaku. Pertanyaan penelitian ini berupaya menentukan tingkat atau tingkat perubahan yang diperkenalkan oleh media sosial.

Tabel 5. Dampak positif dan negatif dari media sosial pada mahasiswi

\begin{tabular}{|c|c|c|c|c|c|c|c|}
\hline Pertanyaan & $S S$ & $S$ & Total & $T S$ & STS & Total & Bimbang \\
\hline \multirow{2}{*}{$\begin{array}{l}\text { Apakah Penggunaan media sosial } \\
\text { menghancurkan nilai-nilai sosial dan } \\
\text { gaya hidup Anda? }\end{array}$} & 0 & 3 & 3 & 25 & 3 & 28 & 9 \\
\hline & 0 & $7.5 \%$ & $7.5 \%$ & $62.5 \%$ & $7.5 \%$ & $70 \%$ & $22.5 \%$ \\
\hline \multirow{2}{*}{$\begin{array}{l}\text { Apakah penggunaan media social } \\
\text { mempromosikan pinjaman budaya } \\
\text { dan tradisi asing? }\end{array}$} & 2 & 25 & 27 & 5 & 2 & 7 & 6 \\
\hline & $5 \%$ & $62.5 \%$ & $67.5 \%$ & $12.5 \%$ & $5 \%$ & $17.5 \%$ & $15 \%$ \\
\hline \multirow{2}{*}{$\begin{array}{l}\text { Penggunaan media sosial membantu } \\
\text { menghancurkan ketidaksetaraan } \\
\text { gender? }\end{array}$} & 1 & 9 & 10 & 17 & 4 & 21 & 9 \\
\hline & $2.5 \%$ & $23 \%$ & $25 \%$ & $42.5 \%$ & $10 \%$ & $52.5 \%$ & $22.55 \%$ \\
\hline \multirow{2}{*}{$\begin{array}{l}\text { Penggunaan media social mendorong } \\
\text { mahasiswi untuk terlibat dalam } \\
\text { politik? }\end{array}$} & 4 & 18 & 22 & 4 & 2 & 6 & 12 \\
\hline & $10 \%$ & $45 \%$ & $55 \%$ & $10 \%$ & $5 \%$ & $15 \%$ & $30 \%$ \\
\hline \multirow{2}{*}{$\begin{array}{l}\text { Penggunaan panggilan, chatting, } \\
\text { berbagi konten, menautkan tautan } \\
\text { media sosial dan banyak lagi } \\
\text { menghabiskan waktu? }\end{array}$} & 4 & 16 & 20 & 17 & 1 & 18 & 2 \\
\hline & $10 \%$ & $40 \%$ & $50 \%$ & $42.5 \%$ & $2.5 \%$ & $45 \%$ & $5 \%$ \\
\hline \multirow{2}{*}{$\begin{array}{l}\text { Penggunaan media sosial telah } \\
\text { mengubah perasaan Anda saat jatuh } \\
\text { cinta pada orang yang bukan orang } \\
\text { Indonesia? }\end{array}$} & 3 & 13 & 16 & 16 & 6 & 22 & 2 \\
\hline & $7.5 \%$ & $32.5 \%$ & $40 \%$ & $40 \%$ & $15 \%$ & $55 \%$ & $5 \%$ \\
\hline \multirow{2}{*}{$\begin{array}{l}\text { Penggunaan media sosial terbaru } \\
\text { berarti bagi Anda untuk menemukan } \\
\text { cinta? }\end{array}$} & 2 & 8 & 10 & 19 & 9 & 28 & 2 \\
\hline & $5 \%$ & $20 \%$ & $25 \%$ & $48 \%$ & $23 \%$ & $70 \%$ & $5 \%$ \\
\hline \multirow{2}{*}{$\begin{array}{l}\text { Penggunaan media sosial telah } \\
\text { menghancurkan hubungan Anda } \\
\text { dengan keluarga, teman, dan teman } \\
\text { kuliah? }\end{array}$} & 1 & 3 & 4 & 22 & 13 & 35 & 1 \\
\hline & $2.5 \%$ & $7.5 \%$ & $10 \%$ & $55 \%$ & $33 \%$ & 87.5 & $2.5 \%$ \\
\hline \multirow{2}{*}{$\begin{array}{l}\text { Tidak efektifnya penggunaan media } \\
\text { sosial menghancurkan hubungan } \\
\text { antar negara? }\end{array}$} & 9 & 16 & 25 & 8 & 3 & 11 & 4 \\
\hline & $22.5 \%$ & $40 \%$ & $62.5 \%$ & $20 \%$ & $70 \%$ & $27.5 \%$ & $10 \%$ \\
\hline \multirow{2}{*}{$\begin{array}{l}\text { Penggunaan media sosial adalah } \\
\text { menjadi adiktif bagi mahasiswi? }\end{array}$} & 5 & 15 & 20 & 10 & 1 & 11 & 9 \\
\hline & $12.5 \%$ & $37.5 \%$ & $50 \%$ & $25 \%$ & $2.5 \%$ & $27.5 \%$ & $22.5 \%$ \\
\hline \multirow{2}{*}{$\begin{array}{l}\text { Apakah media sosial mempengaruhi } \\
\text { bagaimana Anda berkomunikasi atau } \\
\text { berbicara dengan orang yang lebih } \\
\text { tua? }\end{array}$} & 8 & 21 & 29 & 10 & 0 & 10 & 1 \\
\hline & $20 \%$ & $53 \%$ & $72.5 \%$ & $25 \%$ & 0 & $25 \%$ & $2.5 \%$ \\
\hline
\end{tabular}


Tingkat perubahan yang dikaitkan dengan media sosial dapat menjadi positif atau negatif pada mahaasiswi. Pertanyaan pertama pada tabel 5 diarahkan untuk memahami apakah media sosial menghancurkan nilai-nilai sosial dan gaya hidup mahasiswi. Menurut temuan penelitian, 28 (70\%) dari peserta tidak setuju bahwa media sosial menghancurkan nilai-nilai sosial dan gaya hidup mereka. Sementara $3(7.5 \%)$ bertentangan dengan menyetujui bahwa media sosial menghancurkan nilai-nilai dan gaya hidup mahasiswi yang merupakan dampak negatif. Pada titik ini, penelitian membuktikan bahwa media sosial tidak menghancurkan nilai-nilai sosial dan gaya hidup mahasiswi. Meskipun ada tingkat dampak pada perilaku dan semua itu. Budaya adalah elemen konstruksi sosial. Menurut temuan pada tabel 5, pertanyaan kedua berusaha untuk memahami apakah media sosial mempromosikan pinjaman budaya dan tradisi asing. Temuan menunjukkan 27 (67.5\%) dari responden setuju bahwa media sosial mempromosikan mahasiswi untuk meminjam dan mengadopsi budaya dan tradisi asing. Temuan ini menggambarkan bahwa penggunaan media asing oleh mahasiswi mepmengaruhi adopsi gaya hidup dan tradisi asing mereka.

\section{Masyarakat ada pada gender dan ketidaksetaraan sosial.}

Pertanyaan ketiga pada tabel 5 bertujuan untuk menjawab apakah media sosial membantu dalam memecahkan kesenjangan gender dan ketidaksetaraan dalam masyarakat saat ini. Temuan menunjukkan bahwa 10 (25\%) menerima bahwa media sosial membantu dalam memecahkan dan menghancurkan ketidaksetaraan gender di antara siswa. Sementara sebaliknya, 21 (52.5\%) menyatakan bahwa media sosial tidak menghancurkan ketidaksetaraan gender di antara gender di masyarakat kita. Temuan ini sangat membuktikan bahwa media sosial tidak mempromosikan pengetahuan dan ide-ide untuk melucuti ketidaksetaraan dan ketidakseimbangan gender dalam masyarakat.

Temuan lebih lanjut berlanjut pada baris keempat yang menyiratkan bahwa 22 (55\%) dari peserta percaya bahwa media sosial mendorong mereka melalui konten dan kegiatannya untuk bergabung atau mengembangkan minat dalam politik. Sebaliknya, 6 (15\%) menyarankan bahwa media social tidak mendorong mereka untuk bergabung atau terlibat dalam latihan dan kegiatan politik. Secara sederhana, temuan menunjukkan bahwa konten media sosial, dan pandangan tentang isu-isu politik membawa inspirasi yang baik bagi mahasisiwi untuk bergabung, terlibat dalam diskusi dan tugas politik dalam masyarakat saat ini.

Temuan lebih lanjut menyinggung bahwa berbagai kegiatan yang dilakukan di media sosial seperti chatting, menyukai konten, melakukan panggilan (audio dan video) dan banyak lainnya, memakan waktu untuk mahasiswi. Indikasi (50\%) telah membuktikan bahwa keterlibatan 
berkelanjutan pada media sosial oleh mahasiswi untuk berbagai jenis kegiatan memakan waktu dan mengganggu. Kumpulan pertanyaan lain berusaha untuk dipahami dari peserta jika penggunaan media sosial oleh mahasiswi membawa perubahan pada bagaimana mereka jatuh cinta dengan pria yang bukan berasal dari Indonesia. Perubahan adalah hal yang konstan di media sosial di masa hidup kita. Menurut Al-Sharq et al. (2015), media sosial telah mengubah wajah institusi akademik bersama dengan pengguna. Perubahan ini juga mencerminkan bagaimana perasaan pengguna, pemikiran, alasan, tindakan, penerimaan, transfer ide dan konten, dan lainnya. Temuan penelitian memberikan kejelasan bahwa $16(40 \%)$ merasa bahwa karena media sosial pilihan mereka dan peluang untuk berada dalam hubungan romantis atau cinta dengan pria Indonesia ditingkatkan. Sementara, $22(55 \%)$ juga tidak setuju dengan temuan ini dengan mengatakan bahwa media sosial tidak mengubah apa pun yang mereka rasakan tentang laki-laki bukan Indonesia. Temuan ini menyoroti bahwa media sosial sedang sibuk mengubah dan mempromosikan hubungan antar ras, suku, dan negara, tetapi banyak yang masih meremehkan pandangan dengan menyinggung bahwa media sosial tidak mengubah pendirian cinta mereka terhadap laki-laki bukan Indonesia.

Di akun lain, peserta dibuat untuk menyatakan apakah media sosial adalah platform atau media terbaru yang mereka gunakan untuk menemukan cinta. Cinta adalah unsur penting yang mengikat manusia bersama. Berdasarkan ini, sebuah pertanyaan diajukan "apakah penggunaan media sosial cara terbaru bagi Anda untuk menemukan cinta?", 28 (70\%) dengan jelas menyatakan bahwa media sosial bukan media terbaru atau sarana bagi mereka untuk menemukan cinta dan kasih sayang. Temuan selanjutnya menunjukkan bahwa 10 (25\%) dari responden setuju bahwa media sosial adalah cara terbaru dalam menemukan cinta dan kasih sayang.

Temuan keseluruhan menunjukkan bahwa mahasiswi tidak menggunakan media sosial hanya untuk pencarian cinta, namun, beberapa responden merasa bahwa media sosial telah membuka pintu baru di dunia hubungan sebagai media terbaru untuk menemukan cinta.

\section{Melawan semua peluang dan dampak negatif media sosial di antara kaum muda.}

Penelitian ini mencoba untuk menilai apakah "media sosial menghancurkan keluarga, teman dan teman sekelas", temuan menunjukkan fakta bahwa 35(87,5\%) dari responden tidak setuju bahwa media sosial menghancurkan hubungan keluarga, teman dan teman hidup. Semua indikasi membuktikan bahwa penggunaan media sosial oleh mahasiswi tidak benar-benar membahayakan keluarga, teman dan hubungan dan nilai teman sekelas mereka.

Pertanyaan selanjutnya berfokus pada penggunaan media sosial yang tidak efektif yang menghancurkan hubungan dan interaksi antar negara. Temuan pada tabel 5 menemukan bahwa 25 
(62.5\%) dari responden menerima bahwa penggunaan atau penerapan media sosial yang tidak efektif menghancurkan pemahaman, interaksi dan hubungan antar negara karena konten yang tidak etis dan posting gambar. Perselisihan juga mengindikasikan bahwa 11 (27.5\%) tidak setuju dengan menyatakan bahwa media sosial tidak menghancurkan hubungan dan perusahaan antar-negara. Temuan ini memuji fakta bahwa media sosial tidak memengaruhi kerja sama dan hubungan antar negara.

Temuan penelitian Mingle dan Adams (2015) menunjukkan bahwa penggunaan media sosial meningkatkan kecanduan di kalangan siswa dan remaja. Temuan mereka sejalan dengan hasil penelitian ini yang menunjukkan bahwa 20 (50\%) dari responden menyatakan mahasiswi kecanduan dalam menggunakan media sosial yang dapat dilihat sebagai sisi negatif dari aplikasi dan platform. Temuan keseluruhan membuktikan bahwa penggunaan media sosial di kalangan mahasiswi menjadi kecanduan bagi mereka.

\section{Menghormati dan menghargai orang lanjut usia dapat dipandang sebagai norma sosial.}

Sebagai hasil dari media sosial, banyak hal tentang sikap dan standar sosial telah berubah dalam waktu belakangan ini. Kemudian sebuah pertanyaan diberikan, yaitu "apakah media sosial memengaruhi cara Anda berkomunikasi atau berbicara dengan orang yang lebih tua?". Pertanyaan ini untuk memahami apakah mahasiswi yang menganggap orang yang lebih tua telah berubah atau dipengaruhi oleh media sosial. Temuan menunjukkan, 29 (72.5\%) dari peserta setuju bahwa media sosial telah mendefinisikan bagaimana mereka berkomunikasi, berbicara dan memperlakukan orang lanjut usia. Sementara 10 (25\%) mengusulkan sebaliknya bahwa media sosial tidak mengubah rasa hormat dan cara berkomunikasi dengan orang tua. Penelitian ini dapat menyatakan bahwa mahasiswi yang menghormati orang lanjut usia telah banyak menurun karena pengaruh media sosial

Penggunaan aplikasi dan platform media sosial mahasiswi bergema secara luas di negaranegara berkembang seperti Indonesia dan di tempat lain. Temuan menunjukkan bahwa whatsapp adalah aplikasi media sosial yang paling banyak digunakan yang digunakan oleh mahasiswi. Sisa dari temuan penelitian ini disajikan sebagai berikut:

Dampak media sosial pada gaya hidup sosial mahasiswi

1. Media sosial benar-benar berdampak pada gaya hidup sosial mahasiswi, mempengaruhi pandangan mereka tentang kehidupan secara umum.

2. Untuk persentase yang lebih besar, media sosial mempromosikan norma-norma dan nilainilai sosial yang baik dan sehat yang membuktikan tanda positif dalam masyarakat. 
3. Secara luar biasa, mahasiswi menyatakan bahwa penempatan konten dan tautan yang tidak relevan, rasis, kasar, anti-budaya dan agama mempromosikan kebencian di antara kelompok ras di masyarakat.

4. Responden juga berpendapat bahwa penggunaan media sosial oleh mahasiswi tidak merendahkan pemikiran, penghargaan, dan nilai pernikahan sebagai lembaga di masyarakat.

5. Sikap dan persepsi mahasiswi pada media sosial berdampak pada gaya hidup sosial mereka

6. Mahasiswi memiliki sikap dan persepsi yang baik tentang media social sebagai bantuan untuk pengajaran dan pembelajaran (pendidikan) di masyarakat saat ini. Sikap dan persepsi mereka juga membuktikan bahwa media sosial secara negatif mempengaruhi interaksi pribadi dan gaya hidup sosial di masyarakat.

7. Temuan ini juga menemukan bahwa mahasiswi tidak percaya bahwa media sosial mempromosikan posting video, gambar, dan gambar yang tidak bermoral dan tidak etis di kalangan siswa. Posting terkadang mengarah ke tampilan konten pribadi / pribadi dan gambar online untuk dilihat publik.

8. Studi ini juga menemukan bahwa mahasiswi tidak percaya penggunaan media sosial mempromosikan dan menciptakan informasi yang tidak perlu dan kebingungan di benak mahasiswi.

9. Sikap dan persepsi mahasiswi membuktikan bahwa media sosial dapat berdampak positif, namun dampak ini sangat bergantung pada penggunaan yang efektif.

Dampak media sosial pada konstruksi gaya hidup sosial mahasiswa sesuai dengan hierarki yang di tunjukkan pada Tabel 6

Tabel 6: Hierarki Kontruksi Dampak Gaya Hidup Sosial

\begin{tabular}{|l|l|}
\hline No & \multicolumn{1}{|c|}{ Hierarki konstruksi dampak gaya hidup sosial } \\
\hline 1. & Pemikiran \\
\hline 2. & Pendapat dalam hidup dan ketertarikan/hobi/minat \\
\hline 3. & Budaya \\
\hline 4. & Orientasi perilaku (kelompok dan individu) \\
\hline 5. & Tingkah laku \\
\hline 6. & Posisi sosial \\
\hline 7. & Tindakan \\
\hline 8. & Kepercayaan \\
\hline 9. & Norma \\
\hline 10. & Asosiasi \\
\hline
\end{tabular}




\section{Perluasan media sosial mengubah gaya hidup sosial mahasiswi.}

Dampak media sosial pada siswa perempuan dapat menjadi positif atau negatif.

Dampak positif dari media sosial pada gaya hidup sosial mahasiswi:

1. Media sosial tidak merusak nilai-nilai dan gaya hidup sosial.

2. Media sosial juga mendorong siswa perempuan untuk terlibat dalam politik.

3. Menurut temuan, peserta menegaskan bahwa penggunaan media sosial tidak mempengaruhi bagaimana mereka jatuh cinta dengan laki-laki bukan Indonesia.

4. Penggunaan media sosial tidak dianggap sebagai saluran terbaru bagi mahasiswi untuk menemukan cinta, tetapi mereka lebih memilih metode tradisional.

5. Penggunaan media sosial oleh mahasiswi tidak menghancurkan hubungannya dengan keluarga, teman, dan teman kuliah

Dampak negatif dari media sosial pada gaya hidup sosial siswa perempuan

1. Media sosial mempromosikan pinjaman budaya dan tradisi asing

2. Media sosial tidak membantu menghancurkan ketidaksetaraan gender, melainkan justru mempromosikannya.

3. Penggunaan fitur media sosial (panggilan, obrolan, berbagi konten, menautkan tautan, dan banyak lagi) menghabiskan waktu mahasiswi.

4. Penggunaan media sosial yang tidak efektif menghancurkan hubungan antar negara.

5. Mahasiswi kecanduan untuk menggunakan media sosial

6. Media sosial mempengaruhi cara mahasiswi berkomunikasi dan berbicara dengan orang yang lebih tua di masyarakat.

7. Secara keseluruhan, penggunaan media sosial mahasiswi mempengaruhi dan berdampak pada interaksi pribadi mereka (gaya hidup sosial)

\section{KESIMPULAN}

Meskipun artikel di media sosial dan pengaruh dalam masyarakat dengan kurang fokus pada mahasiswi, penelitian ini memeriksa dampak penggunaan media sosial pada gaya hidup sosial mahasiswi. Studi ini mampu menemukan beragam dampak dari penggunaan media sosial baik positif maupun negatif yang merupakan hasil dari kemajuan teknologi modern. Sorotan temuan termasuk yang berikut; media sosial melihat bagaimana siswa perempuan berpikir, berinteraksi, berkomunikasi, jatuh cinta, gaya hidup sosial mereka dan banyak lagi. Rekomendasi yang tepat dibuat meliputi; membuat media sosial berorientasi budaya, mahasiswi menghabiskan lebih sedikit waktu di media sosial untuk menghindari kecanduan, mahasiswi harus membatasi mempercayai 
semua yang mereka baca dan tonton di situs media sosial dan orang-orang harus berhenti membuat komentar kasar dan mengirim video tidak etis di media sosial.

Untuk mengelola efek pada masyarakat, penelitian ini mengidentifikasi sejumlah rekomendasi :

1. Situs dan aplikasi media sosial harus berorientasi pada budaya baik dalam konten maupun fitur.

2. Mahasiswi sebaiknya mengurangi waktu dalam menggunakan media sosial karena dapat mengakibatkan kecanduan dan memakan waktu.

3. mahasiswi harus membatasi mempercayai semua yang mereka baca dan tonton di aplikasi situs media sosial.

4. Orang-orang harus berhenti membuat komentar kasar, mengirim video tidak etis di situs dan aplikasi media sosial.

5. Mahasiswi seharusnya tetap menghormati orang lain khususnya orang lanjut usia dan tidak menjadikan media sosial sebagai faktor yang mempengaruhi cara mahasiswi berkomunikasi dan berbicara dengan orang yang lebih tua di masyarakat.

\section{DAFTAR PUSTAKA}

Ahn, J. (2011). The effect of social network sites on adolescents' social and academic development: Current theories and controversies. Journal of the Association for Information Science and Technology, 62(8), 1435- 1445.

Al-Sharqi, L, Hashim, K \& Kutbi, I. (2015). Perceptions of Social Media Impact on student's social behavior : a comparison between arts and science students. International journal of education and social sciend, 2 (4), 122-131.

Chen, C. C. Kaewkitipong L \& Ractham. (2016). Using social media to enrich information systems field trip experience : student's satisfaction and continuance intentions. Computers in Human Behaviour volume 63 pp. 256-263.

Chukwuere, J. E., \& Onyebukwa, C. F. (2017, July). New media and politics: An assessment of 2016 South African local government elections. In Proceedings of International Academic Conferences (No 4607534). International Institute of Social and Economic Sciences.

Edge W. (2017). Nursing Professionalism: Impact of Social Media Use among Nursing Students. Journal of Healthcare Communications, 2(3), 1-3.

Gross. E. F. (2004). Adolescent internet use: what we expect, what teen report. Applied developmental psychology. Vol. 25. Pg. 633-649. 
Gonzales, L.M. dan Hancock, T.J. 2011. Mirror, Mirror on My Facebook Wall: Effects of Exposure to Facebookon Self Esteem. Cyberpsychology, Behavior, and Social Networking. Volume 14 Number 1-2. p: 79-83.

Jha, R. K, Shah, D.K, Basnet, S, Paudel, K. R, Sah, P, Sah, A. K \& Adhikari, K. (2016). Facebook use and its effect on the life of health science students in a private medical of Nepal. Jha et al. BMC Res Notes (2016) 9:378 DOI 10.1186/s13104-016-2186-0.

Junco, R. Helbergert, G \& Loken. E. (2011). The effect of twitter on college student engagement and grades. Journal of Computer Assisted Learning Vol. 27, 119-132

Khan, S. (2012). Impact of social networking websites on students. Abasyn Journal of Social Sciences, 5(2), 56-77.

Lowisz, S. (2014). The Influence of Social Media on Today's Culture. tevelowisz.com/wp.../02/The- Influence-of-Social-media-in-Todays-Culture-wp.pdf

Makinde, O. A, Odimegwu. C. O, Abdulmlik, J. O, Babalola, S. O \& Fawole, O. I. (2016). GenderBased Violence following Social Media Acquaintance in Nigeria. African Journal of Reproductive Health December Vol. 20 (4): 67

Mingle, J \& Adams, M. (2015). Social Media Network Participation and Academic Performance In Senior High Schools in Ghana. Library Philosophy and Practice (e-journal). htp://digitalcommons.unl.edu/libphilp rac/1286.

Moate, K. M., Chukwuere, J. E., \& Mavhungu, M. B. (2017, July). The impact of wireless fidelity on student's academic performance in a developing economy In Proceedings of International Academic Conferences (No. 4607490). International Institute of Social and Economic Sciences.

Nyangeni, T., Du Rand, S \& Van Rooyen, D. (2015). Perception of nursing students regarding responsible use of social media in Eastern Cape. Curationis 38(2), Art. \#1496, 9 pages. http://dx.doi. org/10.4102/curationis. v38i2.1496

Rajeev, M. M. J, (2015). Effects of Social Media on Social Relationships: A Descriptive Study on the Impact of Mobile Phones among Youth Population. 4(2), 11-16.

Shabir, G., Hameed, Y. M. Y., Safdar, G., \& Gilani, S. M. F. S. (2014). The Impact of Social Media on Youth: A Case Study of Bahawalpur City. Asian Journal of Social Sciences and Humanities, 3(4), 132-151.

Williams, L. M. (2012). Facebook ruined my marriage: Digital intimacy interference on social networking sites (Doctoral dissertation, Syracuse University) 
Wolf, D.M, Wenskovitch, J \& Anton, B.B. (2016). Nurse use of the internet and social media: Does age, years of experience and educational level make a difference? Journal of nursing education and practice, $6(2), 68-75)$.

\section{UCAPAN TERIMA KASIH}

Artikel ini merupakan hasil dari penelitian yang telah dilakukan. Penulisan artikel ini tidak akan pernah terwujud tanpa bantuan dari berbagai pihak. Ucapan terima kasih kepada pihak-pihak yang telah berkontribusi pada semua proses pelaksanaan penelitian dan penerbitan artikel ini.

\section{PROFIL PENULIS}

Rr. Chusnu Syarifa Diah Kusuma adalah dosen di Jurusan Pendidikan Administrasi Fakultas Ekonomi, Universitas Negeri Yogyakarta. 